
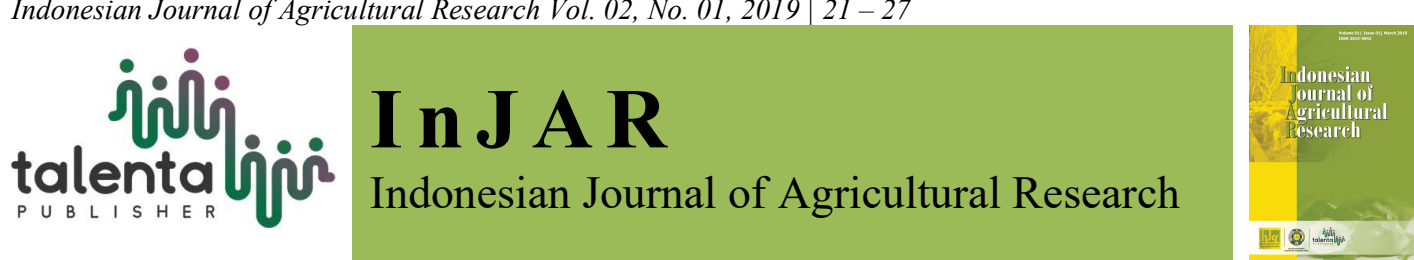

\title{
A Sediment Rating-curve Method to Determine Sediment Discharge for Rainy Season in Micro-scale Watersheds
}

\section{Atikah Sitorus and Edi Susanto}

Department Agricultural Engineering, Universitas Sumatera Utara, Indonesia

\begin{abstract}
This research was carried out to overcome the problem of the lack of sediment data available in several watersheds in North Sumatra, the lack of available sediment data is caused by the requirement of a large amount of time, cost and risk to obtain such data. Purpose of this study was to obtain the equation of sediment rating curve. The sediment rating curve is an equation that connects the river discharge with sediment discharge, so that to obtain the sediment discharge, it is enough to use the river discharge data. This research used the descriptive method using the primary (sediment discharge and concentration data) and secondary data (climate data). Result of the study obtained the equation of the sediment rating curve of $\mathrm{Qs}=14.115 \mathrm{Q}^{2.2736}$ and the value of $\mathrm{R}^{2}$ of 0.711 . The sediment discharge obtained has exceeded the limit set by the Ministry of Forestry regarding the criteria for determination of watersheds.
\end{abstract}

Keywords: discharge, sediment rating curve, sediment discharge, watersheds

Received 11 March 2019 | Revised 30 March 2019 | Accepted 31 March 2019

\section{Introduction}

Watershed is an area bounded by ridges where the rainwater that falls on the area will be accommodated by the ridge and will be channeled through the small rivers, continues to the main river or the watershed which is the geographical area whose water comes from the tributary [1]. Sediment which is the result of a sedimentation process in which the soil from erosion is transported by water from the erosion area and is carried away by the waterflow and settles in a place where the flow velocity slows or decreases [2]. The availability of sediment discharge data in each watershed in North Sumatra is still very limited, because to obtain such data requires a long time, large costs and large energy. With the availability of sufficient sediment discharge data, it is easier for the stakeholders to see how well the watershed management has been carried out. The sediment rating curve method could be used to overcome the lack of sediment data from each watershed, with this method, the sediment rating curve will be obtained, which is an equation that

\footnotetext{
*Corresponding author at: Department Agricultural Engineering, Faculty of Agriculture, Universitas Sumatera Utara, Jl. Prof. Sofyan No 3, Medan, Indonesia

E-mail address: edi.susanto@usu.ac.id
} 
connects the river discharge with sediment discharge. Therefore, usage of the river discharge data is enough to obtain the sediment discharge data.

Sediment discharge expressed in unit of time could be obtained by several methods such as the calculation of sediment discharge $(\mathrm{Qs})$, flowrate $(\mathrm{Qw})$, sediment concentration $(\mathrm{C}), 0.0864$ (Constant) by using the equation of the sediment rating curve [3] [4]. In general, the published scientific works that use the sediment rating curve are the power function in the form of equations as below [5] [6]. Purpose of this study was to obtain the sediment rating curve equation in a watershed.

\section{Materials and Methods}

\subsection{Time and Location}

This research was conducted in July to November 2018, located in the upstream part of Deli watershed or Sei Petani sub-watershed, which is between $03^{\circ} 12^{\prime} 52.81^{\prime \prime}$ to $03^{\circ} 47^{\prime} 06,11^{\prime \prime} \mathrm{LU}$ and $98^{\circ} 29^{\prime} 23.32^{\prime \prime}$ to $98^{\circ} 42^{\prime} 49.79^{\prime \prime}$ BT (Figure 1). The materials used in this study were sediment samples, data such as the soil type map, DEM (Digital Elevation Mode) map, land use map and climate data. The other supporting materials were river discharge data, soil physical characteristics data, while the equipment used were bottles used to store the sediments, whatman filter paper type of 934-AH, a set of computer with arcGIS, water level logger, current meter and rainfall logger.

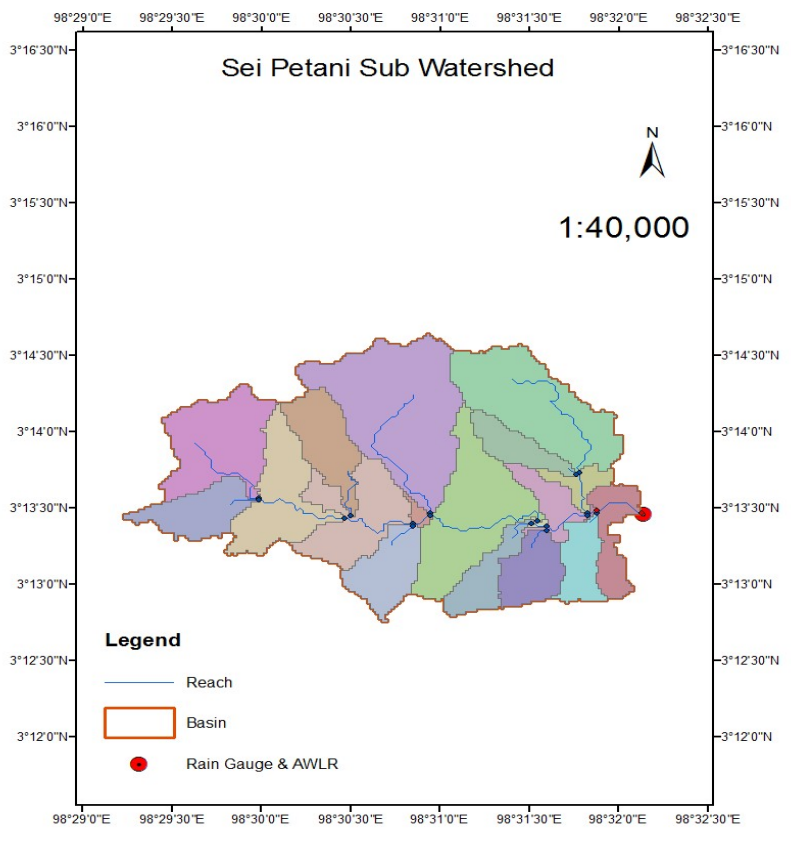

Figure 1. Research Location 


\subsection{Research Procedure}

This research used descriptive method by using the primary and secondary data. Figure 2 shows the stages of the research carried out, namely the determination of study location, the installation of water logger and bottles of water samples, sediment analysis, establishment of the sediment rating curve equation and model evaluation. The secondary data included climate data, DEM map and land cover data. Primary data was obtained by a direct measurement at the River Flow Measurement Station, in the form of river flow velocity (v) using a current meter and the wet cross-sectional area (A) performed every week and then calculating the amount of discharge using the formula of $\mathrm{Q}=\mathrm{V}$.A. The river water level measurement was carried out automatically every 30 minutes using the water level logger. The other primary data in the form of sediment water samples were taken from the sample bottles that have been placed on the river bank, the height of the bottles represent some magnitude of the river discharge that occurs. Sediment concentration was obtained by an analysis using gravimetric method [7]. The other primary data in the form of rainfall data obtained from the rainfall logger devices installed on river flow measuring station (RFMS).

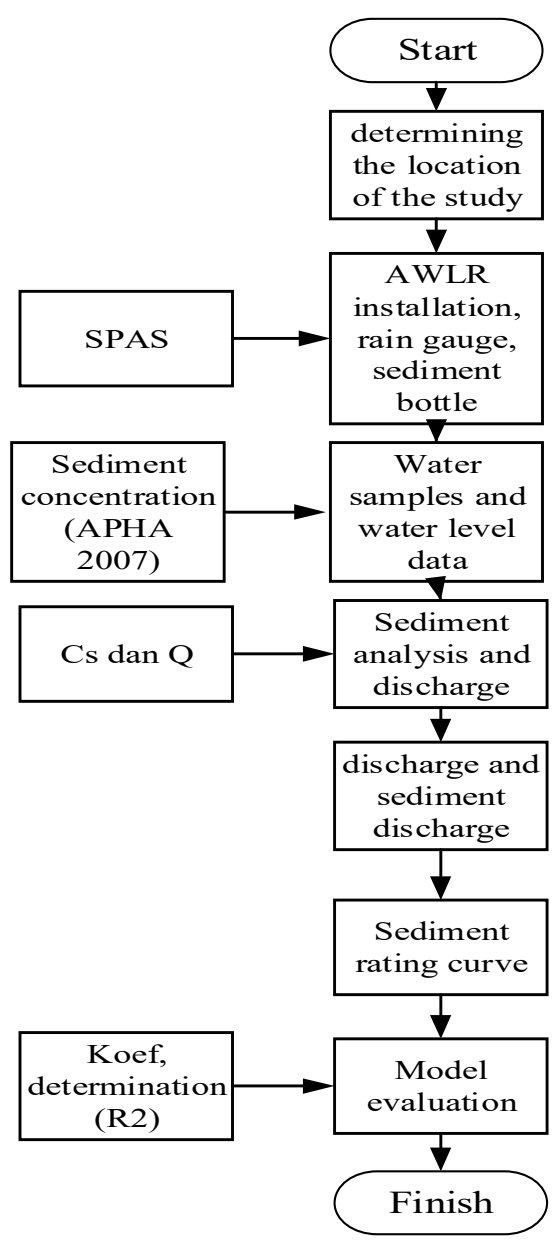

Figure 2. Research Procedure 


\subsection{Determination Step of the Sediment Rating Curve Equation and Model Evaluation}

At this stage, the relationship graph between the discharge of observations in RFMS and the sediment discharge was conducted, the curve matching (goodness of fit) using the rating curve equation model such as the power function method, then to find out how well the equation model is if compared to the observation data, then the model evaluation was conducted by using the coefficient of determination $\left(\mathrm{R}^{2}\right)$ as recommended by The American of Civil Engineers [8] [9]. The coefficient of determination $\left(\mathrm{R}^{2}\right)$ is an indicator of the relationship strength between the observation value and the simulation value [10], $\mathrm{R}^{2}$ has a range of $0-1$, the value of $\mathrm{R}^{2}$ is satisfactory if the value is above 0.6 .

\section{Results and Discussion}

\subsection{Characteristic of Watershed}

Sub-watershed of Sei Petani has an area of 1191 ha, with an altitude of 1276m - 2064m, and the main river flow length of $5.7 \mathrm{~km}$, and also has land cover in the form of secondary dryland forest with an area of 719.41 ha and a percentage of $60.39 \%$, dryland agriculture with an area of 162.19 ha and a percentage of $13.61 \%$, bushes with an area of 269.69 ha and a percentage of $22.63 \%$ and open land with an area of 39.93 ha and a percentage of $3.35 \%$, and two types of soil namely andosol and podsol.

\subsection{Rainfall, River Discharge, Sediment Concentration and Sediment Discharge}

The rainfall data was obtained by using the rainfall logger that has been installed in RFMS. In Table 1. we can see the highest and the lowest rainfall data which were occured in October 2018 of $281 \mathrm{~mm} / \mathrm{month}$ and in August 2018 of $0.5 \mathrm{~mm} / \mathrm{month}$, respectively.

Table 1. Data of Rainfall and River Discharge

\begin{tabular}{ccc}
\hline Month-Year & Rainfall (mm/month) & River Discharge $\left(\mathrm{m}^{3} /\right.$ second $)$ \\
\hline July-18 & 4.50 & 0.91 \\
August-18 & 0.50 & 0.91 \\
Sept-18 & 5.00 & 0.92 \\
Oct-18 & 281.00 & 1.12 \\
Nov- 18 & 130.5. & 1.53 \\
\hline
\end{tabular}

Table 1 shows the highest distribution of monthly average river discharge that occurred in November 2018, which was $1.53 \mathrm{~m}^{3} /$ second and the lowest monthly river discharge occured in July and August 2018, which was $0.91 \mathrm{~m}^{3} /$ second. The difference of the river water discharge data is due to the differences in the river water level average every day which is caused by the rain which make the water level rise and fall. $70 \%$ of the river upstream has an average slope 
above 8 , which in general, the upstream has a higher rainfall intensity compared to the middle and downstream parts and in the rainy season.

Result showed that the highest sediment discharge value occurred on November $15^{\text {th }} 2018$ at 56840 tons/ha/year and the lowest sediment discharge value occurred on September $4^{\text {th }}, 2018$ at 0.52 tons/ha/year. Differences in the results of sediment discharge data are affected due to the occurrence of sediment transport in the rivers that move by the water flow, which is very closely related to soil erosion due to rain. Sediment transport depends on the changes in the rainy and dry seasons and is influenced by human activity [2]. The largest amount of sediment discharge occured in November at 56840 tons/ha/year. The sediment discharge value has exceeded the permissible erosion value (EDP), which is 7 tons/ha/year, this is due to the presence of the land cover in the form of open land and the high land slope [11].

In Figure 3. shows that the relationship of the river discharge (Q) has a movement which is similar to the sediment discharge (Qs). This is because the river flow is not only has the carrying capacity of various sources of erosion that enter the river channel, but also has the power to erode the river banks and make it into another form of erosion donation. The kinetic power of rain breaks up the soil aggregates which could produce erosion materials, but a time process is required to make the soil aggregates to be transported into the river channels. Therefore, a greater rainfall will not necessarily cause a greater sediment discharge [12].

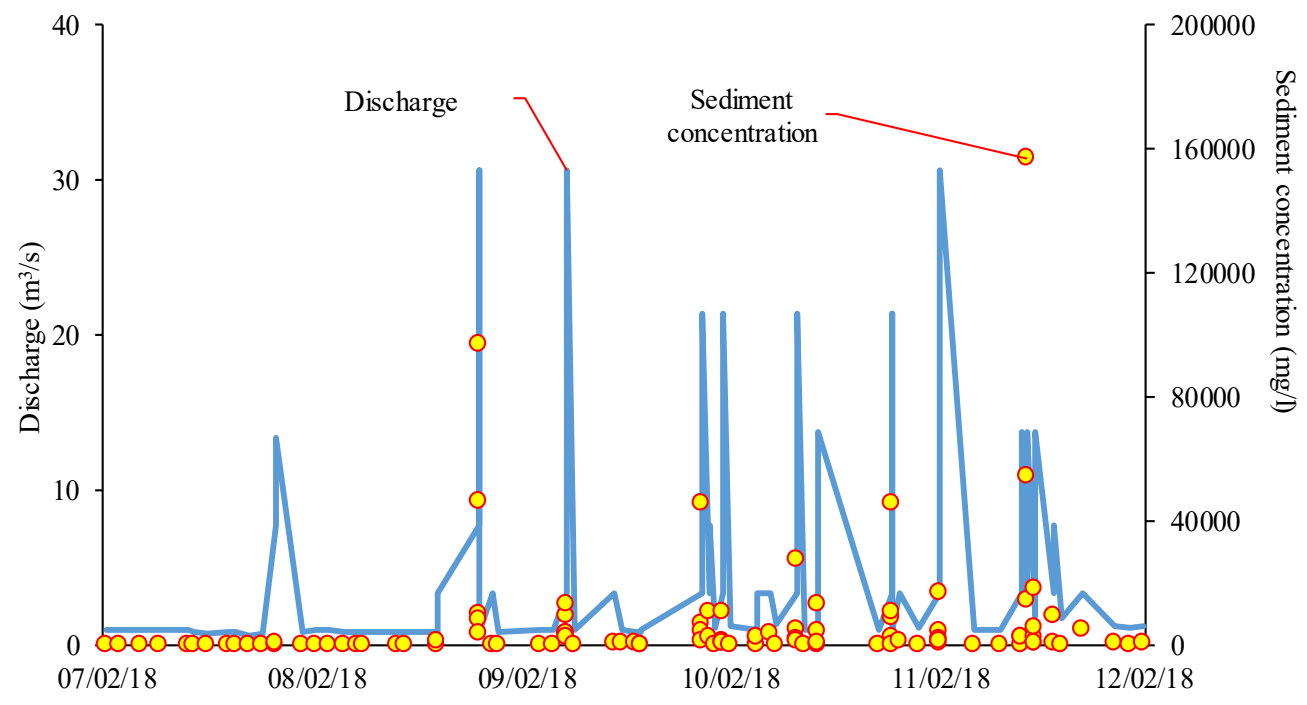

Figure 3. Graph of Sediment Discharge and Concentration Relationship

\subsection{Sediment Rating Curve}

Sediment sampling was carried out together with data collection of river and sediment discharge, so that a relationship could be made between those two data. In making sediment rating curve, the discharge and sediment load data that could represent conditions with large flow, normal flow, 
and small flow should be used. Figure 3. shows $\mathrm{Qs}=14.115 \mathrm{Q}^{2.2736}$ and $\mathrm{R}^{2}=0.711$. From the value of the above equation, constant value $\boldsymbol{a}$ of 14.115 and constant value $\boldsymbol{b}$ of 2.2736 are obtained. From the equation that has been obtained, the coefficient of determination of 0.711 is included in the satisfying category [8] [9]. This means that $71 \%$ of the sediment discharge that occurs is influenced by the river discharge factor and the equation produced from the sediment rating curve is suitable to be used.

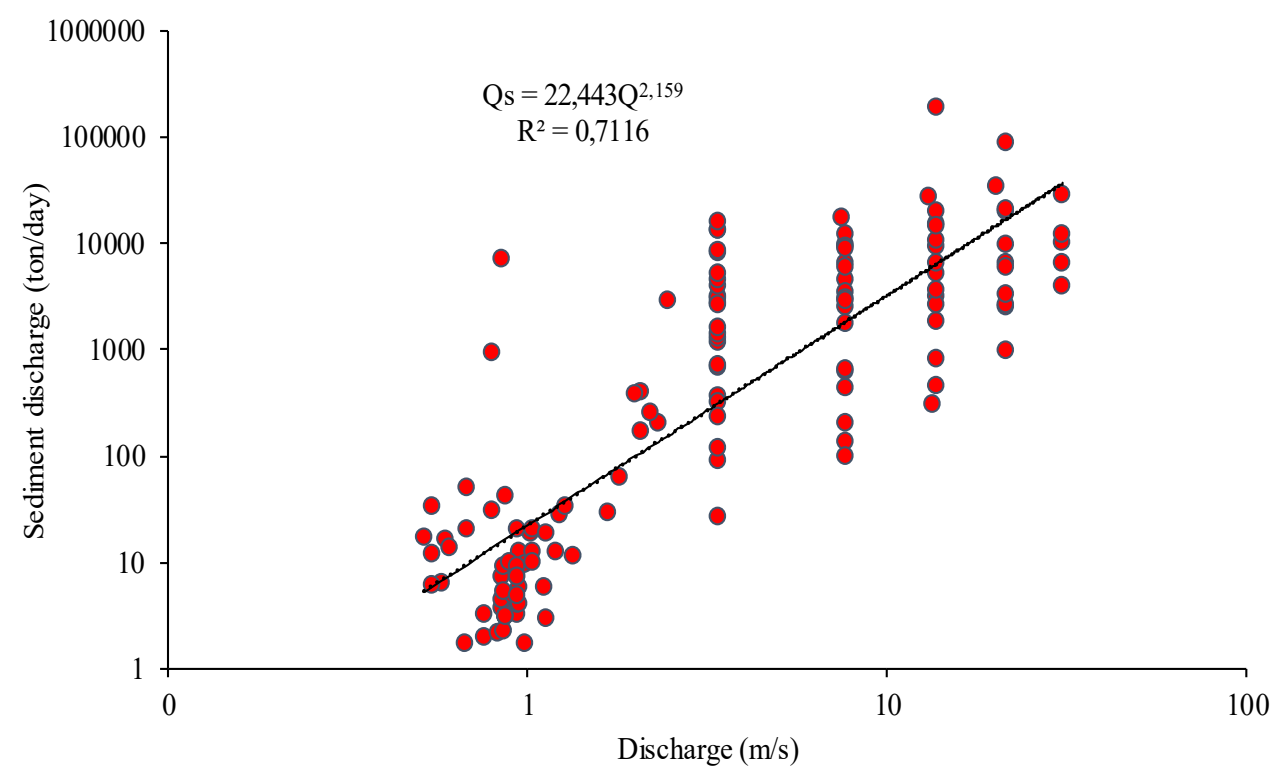

Figure 4. Sediment Rating Curve in Watersheds

\section{Conclusion}

The highest sediment discharge that occurred at the study site was on November $15^{\text {th }}, 2018$ amounting to $185,471.89$ tons/day and the lowest discharge value occurred on September $4^{\text {th }}$, 2018 at 1.70 tons/day. Sediment rating curve obtained with the value of $\mathrm{Qs}=14.115 \mathrm{Q}^{2.2736}$ and the value of $\mathrm{R}^{2}$ of 0.711 . This equation could be used to determine the amount of sediment discharge by only using the river and sediment discharge data in the river at the location of the study.

\section{Acknowledgment}

On this occasion, author would like to thank Universitas Sumatera Utara through the funding of TALENTA Basic Research scheme with the contract number No: 131/UN5.2.3.1/PPM/KPTALENTA USU/2018 for the assistance provided and also to the Management Center of Watershed and Protected Forest Wampu Sei Ular (BPDAS Wampu-Sei Ular), North Sumatera, for providing a place for the research location. 


\section{REFERENCES}

[1] FAO, "Watershed management in action," Rome: Food and Agriculture Organization of the United Nations, 2017.

[2] R. P. C. Morgan, Soil Erosion and Conservation. 3thEd. England (GB): Blackwell Publishing Ltd, 2005.

[3] S. Isik, "Regional rating curve models of suspended sediment transport for Turkey," Earth Sci Inform, vol. 6, no. 2013, pp. 87-98, 2014.

[4] B. R. Colby, "Relationship of sediment discharge to streamflow," US Geol. Survey Open File Report pp. 27-56, 1956.

[5] N. E. M. Asselman, "Fitting and interpretation of sediment rating curves," Journal of Hydrology, vol. 234, no. 2000, pp. 228-248, 2000.

[6] J. P. Syvitski, M. D. Morehead, D. B. Bahr, and T. Mulder, "Estimating fluvial sediment transport: The rating parameters," Water Resources Research, vol. 36, no. 9, pp. 2747-1760, 2000.

[7] APHA, Standard Methods for the Examination of Water and Wastewater part 2540B. 19th ed. Washington DC [US]: American Public Health Association, 1995.

[8] R. S. Ahl, S. W. Woods, and H. R. Zuuring, "Hydrologic calibration and validation of SWAT in a snow-dominated rocky mountain watershed, montana, USA 1," JAWRA Journal of the American Water Resources Association, vol. 44, no. 6, pp. 1411-1430, 2008.

[9] D. N. Moriasi, J. G. Arnold, M. W. Van Liew, R. L. Bingner, R. D. Harmel, and T. L. Veith, "Model evaluation guidelines for systematic quantification of accuracy in watershed simulations," Trans. Asabe, vol. 50, no. 3, pp. 885-900, 2007.

[10] C. Santhi, R. Srinivasan, J. G. Arnold, and J. R. Williams, "A modeling approach to evaluate the impacts of water quality management plans implemented in a watershed in Texas," Environmental Modelling \& Software, vol. 21, no. 8, pp. 1141-1157, 2006.

[11] Permenhut, Peraturan Menteri Kehutanan RI Nomor P.60/Menhut_II/2014 tentang Kriteria Penetapan Klasifikasi Daerah Aliran Sungai. Peraturan Menteri Kehutanan, 2014.

[12] E. Susanto, B. I. Setiawan, Y. Suharnoto, and L. Liyantono, "Evaluation of Water Debit in Oil Palm Plantation Watershed Using the Soil Water Assessment Tool (SWAT)," International Journal of Civil Engineering and Technology, vol. 8, no. 6, pp. 332-341, 2017. 